\title{
Caffeic Acid Phenethyl Ester Mitigates Oxidative Stress and Restores Vascular and Heart Function
}

\begin{abstract}
Oxidative stress, such as increased hydrogen peroxide $\left(\mathrm{H}_{2} \mathrm{O}_{2}\right)$ levels, is a major event initiating pathogenesis of various cardiovascular diseases. The effects of Caffeic Acid Phenethyl Ester (CAPE), a natural antioxidant compound, on oxidative stress-induced cardiac cell damage and vascular/heart dysfunction have not been fully elucidated. In this study, the effects of CAPE were tested in $\mathrm{H}_{2} \mathrm{O}_{2}$-induced $\mathrm{H} 9 \mathrm{c} 2$ cell damage, a hind limb ischemia (I, $30 \mathrm{~min}) /$ reperfusion ( $R, 60 \mathrm{~min})$, and a global heart ischemia (I, $30 \mathrm{~min}) /$ reperfusion ( $R, 60 \mathrm{~min}$ ) conditions. We found that $\mathrm{H}_{2} \mathrm{O}_{2}$ (300 $-700 \mu \mathrm{M}$; n=8) concentration-dependently decreased $\mathrm{H} 9 \mathrm{C} 2$ cell viability accompanied with increased intracellular reactive oxygen species (ROS). $\mathrm{H}_{2} \mathrm{O}_{2}(500 \mu \mathrm{M})$ significantly decreased cell viability to $23 \pm 3 \%$ with a significantly increased intracellular ROS levels by $2.95 \pm 0.6$ fold when compared to the control (both $\mathrm{p}<0.05$ ). By contrast, co-treatment of CAPE (10 to $40 \mu \mathrm{M})$ and $500 \mu \mathrm{M} \mathrm{H} \mathrm{H}_{2}$ $(n=5)$ significantly improved cell viability associated with reduction of intracellular ROS in a concentration-dependent manner $(p<0.05)$. Similarly, CAPE $(0.95 \mathrm{mg} / \mathrm{Kg}$, equivalent to $40 \mu \mathrm{M}$ in blood, $\mathrm{n}=5)$ when given at reperfusion significantly reduced blood $\mathrm{H}_{2} \mathrm{O}_{2}$ levels during reperfusion compared to saline treatment in a rat hind limb I (30 min)/R (60 min) model (all $p<0.05)$. Last, CAPE $(40 \mu \mathrm{M}, \mathrm{n}=5)$ given at beginning of reperfusion for 5 minutes significantly salvage heart tissue and cardiac contractile function when compared to untreated I/R hearts $(n=11$; all $p<0.05)$ during $60 \mathrm{~min}$. reperfusion. The cardio-protective effects of CAPE were significantly abolished by a non-selective nitric oxide synthase inhibitor, NG-nitro-L-arginine methyl ester (50 $\mu \mathrm{M}, \mathrm{n}=5)$ or a heme oxygenase-1 inhibitor, SnPPIX $(20 \mu \mathrm{M}, \mathrm{n}=5)$ (all $\mathrm{p}<0.05)$. These results suggest that CAPE mitigates $\mathrm{H}_{2} \mathrm{O}_{2}$ caused cardiac cell damage and I/R induced vascular and heart dysfunction possibly by reducing oxidative stress and/or increasing heme oxygenase-1 and nitric oxide synthase activity.
\end{abstract}

\section{Introduction}

Prevention and treatment of cardiovascular diseases are a major health challenge worldwide. Although disease development involves many factors, oxidative stress has been well recognized as a major contributor [1]. Normally, cellular Reactive Oxygen Species (ROS) are low and play an important physiological role in cellular signaling. Moreover, any excessive ROS will be disposed by endogenous antioxidant mechanisms, such as superoxide dismutase, catalase, and hemeoxygenase [2]. By contrast, under pathological conditions, ROS are overproduced and overwhelms the antioxidant mechanisms. Subsequently, the excessive ROS would oxidize cellular protein, lipid, and nucleic acid; even cause cell death. Furthermore, oxidative stress can initiate inflammation to recruit leukocytes by disturbing vascular endothelial anti-inflammatory property mainly via reduction of blood nitric oxide bioavailability [3]. A representative intracellular ROS is hydrogen peroxide $\left(\mathrm{H}_{2} \mathrm{O}_{2}\right)$. It is an intermediate product after dismutation of superoxide during superoxide disposal. Also, it has relatively longer half-life, is cell permeable, and can be further converted into hydroxyl radical, which is more harmful than $\mathrm{H}_{2} \mathrm{O}_{2}$ itself [2]. Researchers have demonstrated that Ischemia/Reperfusion

\section{Journal of}

\section{Cardiobiology}

Castellano A, Lefkowitz D, Sandhu R, Kim A, Wieczorek P, Kuhn T, Liu S, Kucharski K, Venditto J, Kuo D, Ibe A, Barsotti R, Young LH and Chen Q*

Department of Bio-Medical Sciences, Philadelphia College of Osteopathic Medicine, USA

*Address for Correspondence

Chen Q, Department of Bio-Medical Sciences, Philadelphia College of Osteopathic Medicine, USA, Tel: 215-871-6153, Fax: 215-871-6869; E-mail: qianch@pcom.edu

Castellano A and Lefkowitz D shared co-first authorship and contributed equally

Submission: 27 October 2020

Accepted: 29 November, 2020

Published: 15 December, 2020

Copyright: ๑ 2020 Chen Q and Castellano A et al. This is an open access article distributed under the Creative Commons Attribution License, which permits unrestricted use, distribution, and reproduction in any medium, provided the original work is properly cited.

(I/R) can cause an increase of $\mathrm{H}_{2} \mathrm{O}_{2}$ in cardiac cells [4]. Moreover, our lab also shows that blood $\mathrm{H}_{2} \mathrm{O}_{2}$ levels are increased accompanied with reduced blood nitric oxide levels during an $\mathrm{I} / \mathrm{R}$ insult in hind limbs of rats [5]. Lower blood nitric oxide indicates vascular endothelial dysfunction during reperfusion. Subsequently, oxidative stress and vascular dysfunction can further induce inflammation, cell damage, and organ dysfunction [6-8]. Therefore, compounds which can counteract $\mathrm{H}_{2} \mathrm{O}_{2}$ may mitigate oxidative stress associated progression in cardiovascular diseases.

Caffeic Acid Phenethyl Ester (CAPE), a naturally compound in honey bee hives, has been shown to exhibit anti-oxidant effects [9]. CAPE shows profound $\mathrm{H}_{2} \mathrm{O}_{2}$ scavenging effects in Human Leukemic HL-60 cells [10]. Moreover, CAPE protects retinal pigment epithelium cells and middle ear epithelial cells against $\mathrm{H}_{2} \mathrm{O}_{2}$ induced cell damage [11,12]. Although CAPE is one of the most important active compounds of propolis, the direct effects of CAPE on $\mathrm{H}_{2} \mathrm{O}_{2}$-induced $\mathrm{H} 9 \mathrm{c} 2$ cell damage and oxidative stress related $\mathrm{I} / \mathrm{R}$ injury have not been fully evaluated. In this study, we first tested the concentration-dependent effects of $\mathrm{H}_{2} \mathrm{O}_{2}$ on $\mathrm{H} 9 \mathrm{c} 2$ cell viability. Second, we evaluated if CAPE can protect $\mathrm{H} 9 \mathrm{c} 2$ cells against an $\mathrm{H}_{2} \mathrm{O}_{2}$ insult. Third, the effects of CAPE on intracellular ROS levels in $\mathrm{H} 9 \mathrm{c} 2$ cells and blood $\mathrm{H}_{2} \mathrm{O}_{2}$ levels under rats' hind limb I/R condition were measured. Lastly, we investigated if CAPE given at reperfusion would protect heart from an $\mathrm{I} / \mathrm{R}$ insult, and further determine if nitric oxide bioavailability or heme oxygenase- 1 would contribute to CAPE's cardioprotective effects.

\section{Materials and Methods}

\section{Experimental animals and ethical statement}

All animal procedures complied with the legal and ethical guidelines established by the Institutional Animal Care and Use Committee at PCOM for care and use of animals. Male SpragueDawley (SD) rats (Charles River, Springfield, MA) were housed in polypropylene cages ( 2 rats in each) on wood shavings and provided free access to food and water. SD rats at 275-325 g (8-10 weeks) were used for the ex vivo and in vivo experiments in this study. 


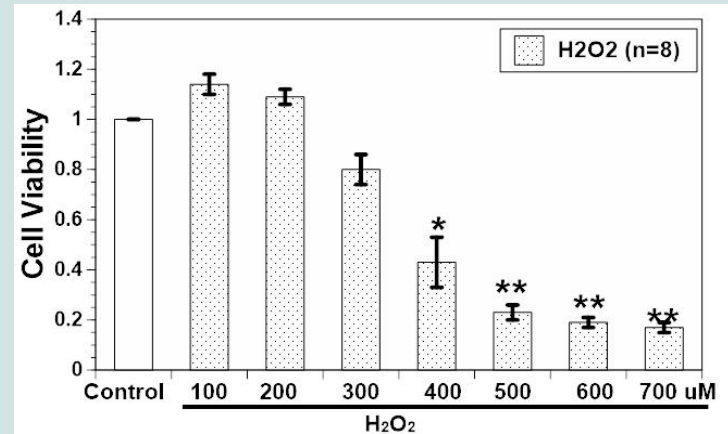

Figure 1: The concentration-dependent effects of $\mathrm{H}_{2} \mathrm{O}_{2}(100-700 \mu \mathrm{M})$ on cell viability after incubation of $\mathrm{H}_{2} \mathrm{O}_{2}$ for $24 \mathrm{hr}$. Cell viability was significantly reduced by higher concentration of $\mathrm{H}_{2} \mathrm{O}_{2}(400-700 \mu \mathrm{M}) .{ }^{*} \mathrm{p}<0.05 ;{ }^{* *} \mathrm{p}<0.01$ vs control.

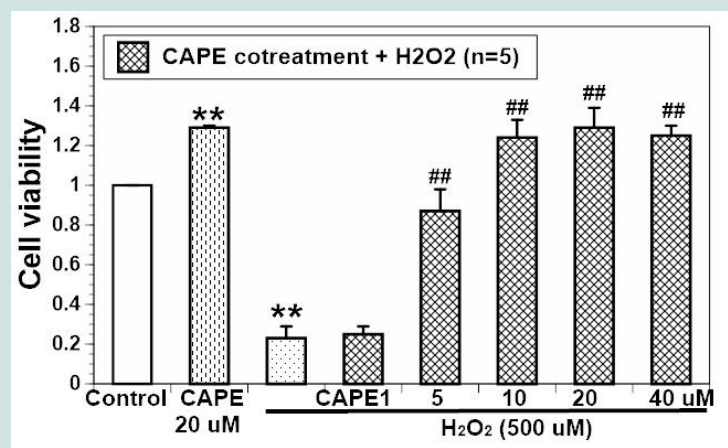

Figure 2: The concentration-dependent effects of CAPE $(1-40 \mu \mathrm{M})$ on cell viability after co-incubation of CAPE and $\mathrm{H}_{2} \mathrm{O}_{2}$ for $24 \mathrm{hr}$. Cell viability was significantly improved by CAPE $(5-40 \mu \mathrm{M}){ }^{* *}{ }^{*}<<0.01$ vs control; \#\#p<0.01 vs $\mathrm{H}_{2} \mathrm{O}_{2}$.

\section{Chemicals and reagents}

CAPE and 2',7'-Dichlorofluorescein Diacetate (DCFDA) were purchased from Abcam (Cambridge, MA, USA). $\mathrm{H}_{2} \mathrm{O}_{2}$, NG-NitroL-arginine methyl ester hydrochloride (L-NAME, a Nitric Oxide Synthase (NOS) inhibitor), and Dimethyl Sulfoxide (DMSO) were obtained from Sigma (St. Louis, MO, USA). Tin Protoporphyrin IX (SnPPIX, a heme oxygenase-1 inhibitor) was purchased from Cayman Chemical (Ann Arbor, MI, USA). Cell Counting Kit-8 assay (CCK-8) was obtained from Dojindo Molecular Technologies (Rockville, MD, USA). Hank's balanced salt solution (HBSS, 10x) without sodium bicarbonate and phenol red was purchased from Gibco Laboratories (Gaithersburg, MD, USA).

\section{Cell Culture and treatments}

Rat H9c2 myoblasts are derived from embryonic BD1X rat heart tissue and were obtained from American Type Culture Collection (ATCC, CRL-1446). Cells were cultured on $75 \mathrm{~cm}^{2}$ culture flasks and petri dishes in high glucose Dulbecco's modified Eagle's medium (DMEM), 1\% penicillin/streptomycin, and 10\% Fetal Bovine Serum (FBS). The cultures were maintained in a humid incubator $\left(5 \% \mathrm{CO}_{2}\right.$ at $37^{\circ} \mathrm{C}$ ) with medium changes every $2-3$ days until $70-80 \%$ confluency. Prior to each experiment, cells were de-attached with trypsin/EDTA and cell density was counted using a hemocytometer after trypan blue
$(0.3 \%)$ staining. Subsequently, cells were seeded into a 96-well plate at density of $2 \times 10^{4}$ cells/well. After incubation for 24 hours, a small amount of medium $(5 \mu \mathrm{l})$ was added to cell wells which were served as the control; whereas $\mathrm{H}_{2} \mathrm{O}_{2}(100-700 \mu \mathrm{M})$, CAPE $(1-40 \mu \mathrm{M})$, or CAPE $(1-40 \mu \mathrm{M})+\mathrm{H}_{2} \mathrm{O}_{2}(500 \mu \mathrm{M})$, was added to treat cells. Cell viability was evaluated after treatments for 24 hours (hr).

\section{Cell viability assay}

Cell viability was estimated in $\mathrm{H} 9 \mathrm{c} 2$ cells using a CCK-8 assay kit (Dojindo Molecular Technologies, Rockville, MD, USA). At the end of treatments, old medium was removed and replaced with new medium, then $10 \mu$ of CCK- 8 solution was administered to each well, and incubated for $4 \mathrm{hr}$. Absorbance at $450 \mathrm{~nm}$ was measured by an iMark Microplate Reader (Bio-Rad Laboratories, Philadelphia, PA, USA). It has been suggested that the amount of absorbance produced after CCK administration is directly proportional to the number of living cells (Dojindo Molecular Technologies). Cell viability was confirmed by observing cell morphology with microscopy. Cell viability is expressed as the ratio between treatments and the control. The control and treatments were conducted in triplets and at least three individual experiments were performed for analysis.

\section{Cell-based intracellular ROS assay}

Intracellular ROS levels were evaluated by using a DCFDA assay. DCFDA is a cell permeable and fluorogenic dye which can be deacetylated by cellular esterases first, then further oxidized by intracellular ROS into a highly fluorescent compound, 2', 7'-Dichlorofluorescein (DCF). Cells were washed twice with phosphate buffer solution (Corning Inc.) and incubated with 25 $\mu \mathrm{M}$ DCFDA (dissolved in a $10 \%$ FBS HBSS) for 45 mins at $37^{\circ} \mathrm{C}$. Afterwards, $\mathrm{H} 9 \mathrm{c} 2$ cells were again washed twice with $\mathrm{PBS}$ to remove DCFDA from incubating solution. Thereafter, medium, $\mathrm{H}_{2} \mathrm{O}_{2}(100-$ $700 \mu \mathrm{M})$, or CAPE $(1-40 \mu \mathrm{M})+\mathrm{H}_{2} \mathrm{O}_{2}(500 \mu \mathrm{M})$ were added to cells. The fluorescence (excited at $480 \mathrm{~nm}$ and emission at $520 \mathrm{~nm}$ ) was measured by using a Fluroskan Ascent CF scanner (Thermo Scientific, San Diego, CA, USA) at baseline, 1 hour and 24 hours posttreatment. The fluorescent signals were normalized to the baseline at time zero before adding treatments. The relative fluorescence served

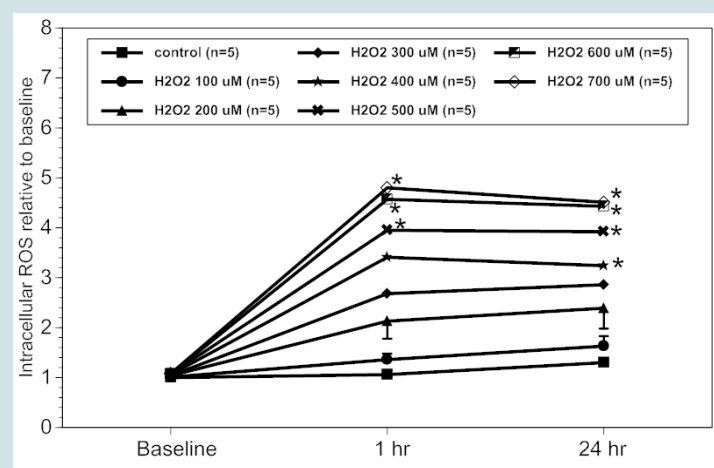

Figure 3: The concentration-dependent effects of $\mathrm{H}_{2} \mathrm{O}_{2}(100-700 \mu \mathrm{M})$ on intracellular ROS levels after incubation of $\mathrm{H}_{2} \mathrm{O}_{2}$ for $1 \mathrm{hr}$ and $24 \mathrm{hr}$. Intracellular ROS levels were significantly increased by higher concentrations of $\mathrm{H}_{2} \mathrm{O}_{2}(400-700 \mu \mathrm{M})$. The error bars for $\mathrm{H}_{2} \mathrm{O}_{2}(300-700 \mu \mathrm{M})$ were omitted for better clarity. The maximal percentage of the mean error bars was $18 \%$. ${ }^{*} \mathrm{p}<0.05$ vs control. 
Citation: Castellano A, Lefkowitz D, Sandhu R, Kim A, Wieczorek P, et al. Caffeic Acid Phenethyl Ester Mitigates Oxidative Stress and Restores Vascular and Heart Function. J Cardiobiol. 2020;7(1): 7.

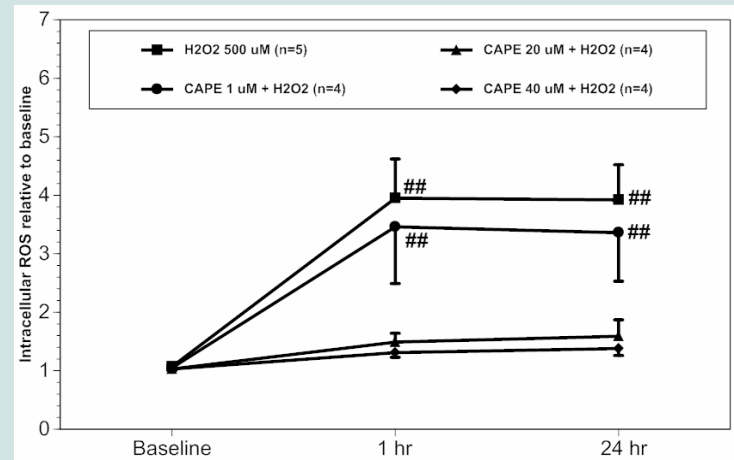

Figure 4: The concentration-dependent effects of CAPE $(1-40 \mu \mathrm{M})$ on intracellular ROS levels after co-incubation of CAPE and $\mathrm{H}_{2} \mathrm{O}_{2}$ for $1 \mathrm{hr}$ and 24 hr. Intracellular ROS levels were significantly reduced by 20 CAPE $\mu \mathrm{M}$ and $40 \mu$ M CAPE. \#\#p<0.01 vs $\mathrm{H}_{2} \mathrm{O}_{2}$.

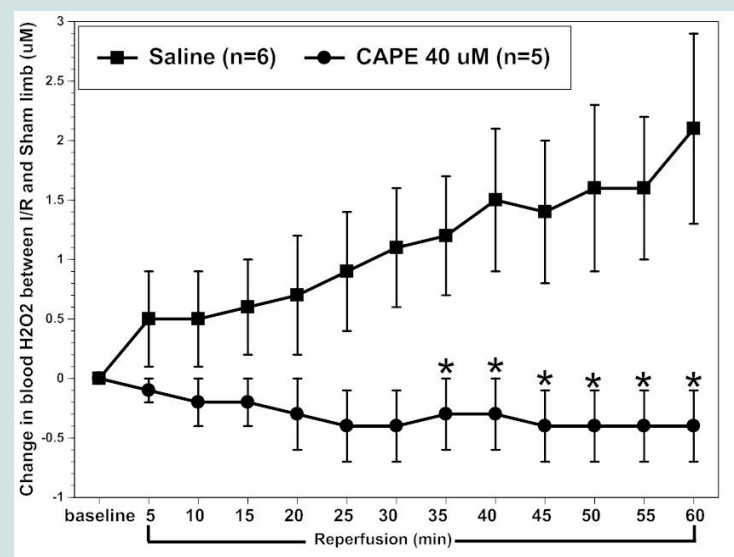

Figure 5: The relative difference of blood $\mathrm{H}_{2} \mathrm{O}_{2}$ levels between I/R limb and sham limb in saline and CAPE $(40 \mu \mathrm{M})$ treated groups during $60 \mathrm{~min}$ reperfusion. CAPE significantly reduced the relative difference of blood $\mathrm{H}_{2} \mathrm{O}_{2}$ levels from 35 minutes to the end of reperfusion. ${ }^{*} p<0.05$ vs saline treatment.

as an index to the production of ROS. The control and treatments were conducted in triplets and at least three individual experiments were performed for analysis.

Measurement of relative blood $\mathrm{H}_{2} \mathrm{O}_{2}$ levels in real-time under $\mathrm{I} / \mathrm{R}$ conditions

Male SD rats were anesthetized with an intraperitoneal (i.p.) injection of $60 \mathrm{mg} / \mathrm{kg}$ sodium pentobarbital for induction and 30 $\mathrm{mg} / \mathrm{kg}$ for maintenance as needed. The hindlimb was dissected to expose the femoral veins and arteries bilaterally. The femoral veins were cannulated with a 24-gauge catheter, and then calibrated $\mathrm{H}_{2} \mathrm{O}_{2}$ microsensors $(100 \mu \mathrm{m}$, World Precision Instruments, Inc., Sarasota, FL) inserted into the catheters bilaterally. The microsensors were connected to a free radical gas analyzer (Apollo 4000, WPI, Inc., Sarasota, FL) which allowed for real-time measurements of blood $\mathrm{H}_{2} \mathrm{O}_{2}$ levels as previously described [5,13]. After stabilization of baseline, one limb was subjected to ischemia via clamping of the femoral artery and vein for 30 minutes (min.) followed by reperfusion by removing the clamp for $60 \mathrm{~min}$. Drugs (CAPE, 0.95 $\mathrm{mg} / \mathrm{Kg}$, equivalent to $40 \mu \mathrm{M}$ in blood) or saline (for non-drug control group) was applied through jugular vein catheter at the beginning of reperfusion. We continuously recorded blood $\mathrm{H}_{2} \mathrm{O}_{2}$ levels in $\mathrm{pA}$ and collect the data at $5 \mathrm{~min}$. intervals during baseline, $30 \mathrm{~min}$. ischemia and $60 \mathrm{~min}$. reperfusion. After experiments, the changes in blood $\mathrm{H}_{2} \mathrm{O}_{2}$ levels were calculated as relative $\mathrm{H}_{2} \mathrm{O}_{2}$ blood levels $(\mu \mathrm{M})$ between I/R limb and sham limb after correction to the calibration curve of $\mathrm{H}_{2} \mathrm{O}_{2}$ microsensors.

\section{Myocardial I/R injury in isolated rat heart}

Langendorff heart preparation was performed after anesthesia of male SD rats (275-325 g, Charles River, Springfield MA) [5,13]. Hearts were isolated and retrograde perfused with Krebs' buffer at a constant pressure of $80 \mathrm{mmHg}$ with $37{ }^{\circ} \mathrm{C}$ and $\mathrm{pH}$ of 7.35-7.45. After 15 min of baseline perfusion, the heart was put through global ischemia by stopping perfusion for $30 \mathrm{~min}$, followed by reperfusion for $60 \mathrm{~min}$. Krebs' buffer alone, $40 \mu \mathrm{M}$ CAPE, $40 \mu \mathrm{M}$ CAPE $+50 \mu \mathrm{M}$

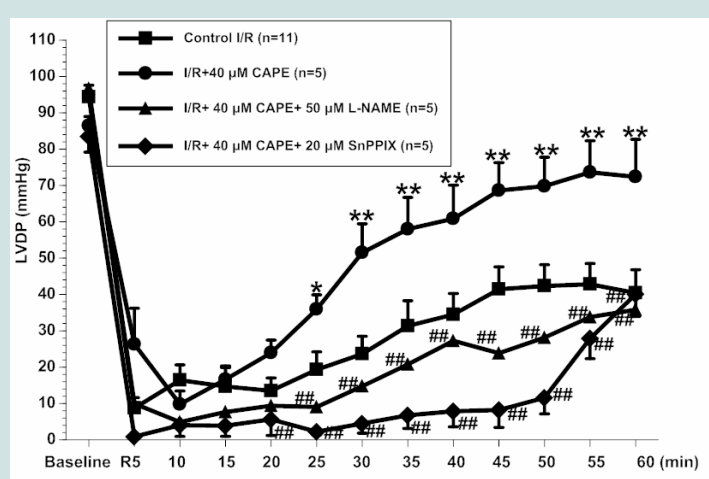

Figure 6: The comparison of LVDP (in $\mathrm{mmHg}$ ) among control $\mathrm{I} / \mathrm{R}, \mathrm{I} / \mathrm{R}+$ CAPE $(40 \mu \mathrm{M}), \mathrm{I} / \mathrm{R}+\mathrm{CAPE}(40 \mu \mathrm{M})+\mathrm{L}-\mathrm{NAME}(50 \mu \mathrm{M})$; and I/R + CAPE $(40$ $\mu \mathrm{M})+$ SnPPIX $(20 \mu \mathrm{M})$. CAPE treatment significantly improved LVDP when compared to control I/R. By contrast, L-NAME or SnPPIX abolished CAPE's effects. The error bars for I/R + CAPE $(40 \mu \mathrm{M})+$ L-NAME $(50 \mu \mathrm{M})$ were omitted for better clarity. The maximal percentage of the mean error bars was $27 \%$. ${ }^{*} p<0.05$; ${ }^{* *} p<0.01$ vs control I/R; \#\#p<0.01 vs CAPE treatment.

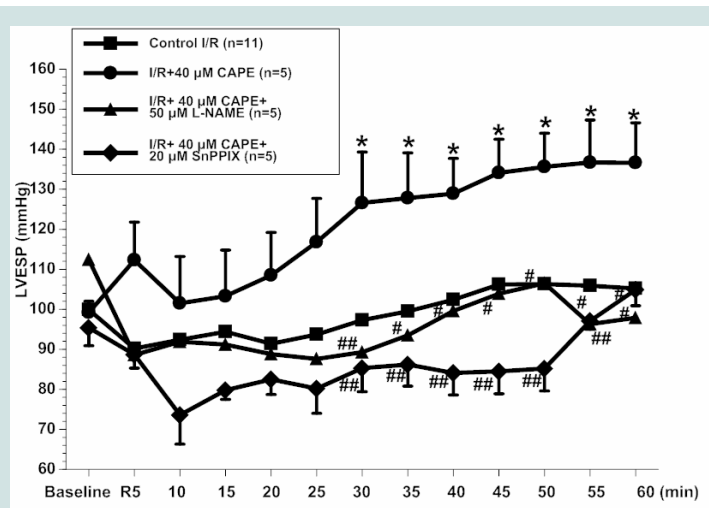

Figure 7: The comparison of LVESP (in $\mathrm{mmHg}$ ) among control $\mathrm{I} / \mathrm{R}, \mathrm{I} / \mathrm{R}+$ CAPE $(40 \mu \mathrm{M}), \mathrm{I} / \mathrm{R}+\mathrm{CAPE}(40 \mu \mathrm{M})+\mathrm{L}-\mathrm{NAME}(50 \mu \mathrm{M}) ;$ and I/R + CAPE $(40$ $\mu M)+\operatorname{SnPPIX}(20 \mu \mathrm{M})$. CAPE treatment significantly improved LVESP when compared to control I/R. By contrast, L-NAME or SnPPIX abolished CAPE's effects. The error bars for control I/R and I/R + CAPE $(40 \mu \mathrm{M})+\mathrm{L}-\mathrm{NAME}$ $(50 \mu \mathrm{M})$ were omitted for better clarity. The maximal percentage of the mean error bars was $16 \%$. ${ }^{*} p<0.05 ;{ }^{* *} p<0.01$ vs control I/R; $\# p<0.05 ; \# p<0.01$ vs CAPE treatment. 


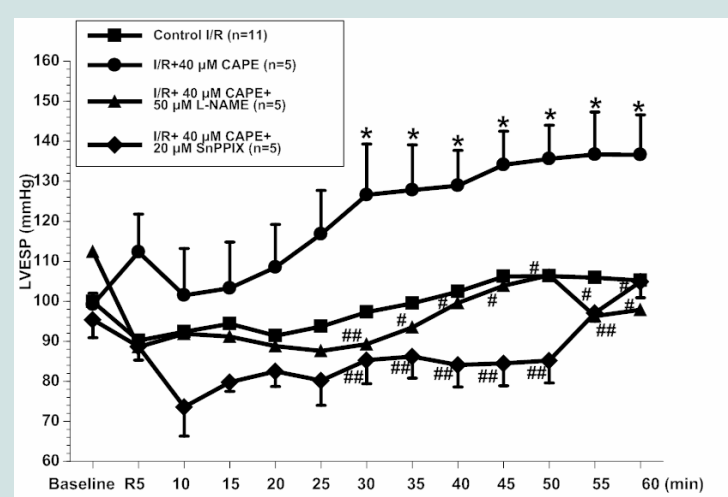

Figure 8: The comparison of $\mathrm{dP} / \mathrm{dtmax}(\mathrm{mmHg} / \mathrm{sec})$ among control I/R, I/R + CAPE $(40 \mu \mathrm{M}), \mathrm{I} / \mathrm{R}+\mathrm{CAPE}(40 \mu \mathrm{M})+\mathrm{L}-\mathrm{NAME}(50 \mu \mathrm{M}) ;$ and I/R + CAPE $(40 \mu \mathrm{M})+$ SnPPIX $(20 \mu \mathrm{M})$. CAPE treatment significantly improved LVDP when compared to control I/R. By contrast, L-NAME or SnPPIX abolished CAPE's effects. The error bars for I/R + CAPE $(40 \mu \mathrm{M})+\mathrm{L}-\mathrm{NAME}(50 \mu \mathrm{M})$ were omitted for better clarity. The maximal percentage of the mean error bars was $27 \%$. ${ }^{*} p<0.05 ;{ }^{* *} p<0.01$ vs control l/R; \#p<0.05; \#\#p<0.01 vs CAPE treatment.

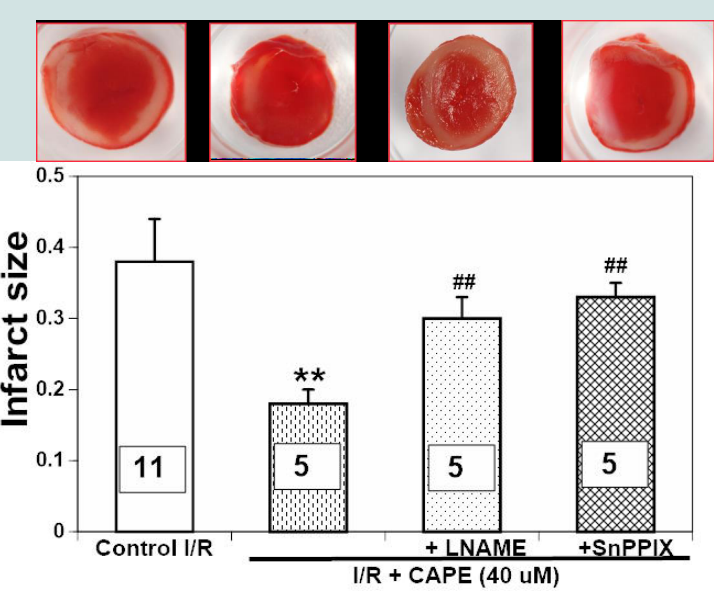

Figure 9: The representative TTC staining pictures (above) and comparison of infarct size (bottom) among control I/R, I/R + CAPE (40 $\mu \mathrm{M}), \mathrm{I} / \mathrm{R}+\mathrm{CAPE}$ $(40 \mu \mathrm{M})+$ L-NAME $(50 \mu \mathrm{M}) ;$ and I/R + CAPE $(40 \mu \mathrm{M})+\operatorname{SnPPIX}(20 \mu \mathrm{M})$ CAPE treatment significantly reduced infarct size when compared to control I/R. By contrast, L-NAME or SnPPIX abolished CAPE's effects. ${ }^{* *} p<0.01$ vs control I/R; \#\#p<0.01 vs CAPE treatment.

L-NAME, or $40 \mu \mathrm{M}$ CAPE $+20 \mu \mathrm{M}$ SnPPIX was infused with $1 \mathrm{ml} /$ min during the first $5 \mathrm{~min}$ of reperfusion. A pressure transducer (SPR524, Millar Instruments, Inc., Houston, TX) was inserted into the left ventricle to record Left Ventricular End Systolic Pressure (LVESP), Left Ventricular End Diastolic Pressure (LVEDP), maximal rate of left ventricular systolic pressure over time (dP/dtmax), minimal rate of left ventricular diastolic pressure over time ( $\mathrm{dP} / \mathrm{dtmin})$, and heart rate. Moreover, left ventricular developed pressure was calculated by the difference between LVESP and LVESP. Coronary flow was measured by a flow probe (T106, Transonic Systems, Inc., Ithaca, NY) which was placed in line with perfusion line. Data was recorded using a Powerlab Station acquisition system (AD Instruments, Grand Junction, $\mathrm{CO}$ ) every $5 \mathrm{~min}$ during the baseline and reperfusion phases.

At the end of the experiments, the left ventricle of the hearts was sectioned into $2 \mathrm{~mm}$ thick slices that were subjected to $1 \%$ Triphenyltetrazolium Chloride (TTC) staining to detect infarcted (unstained) and viable (stained brick red) area. Infarct size was expressed as the percentage of infarcted tissue weight to the total tissue weight [14].

\section{Statistical analysis}

All data were presented as means \pm S.E.M. The data was analyzed by ANOVA using post hoc analysis with Student-Newman-Keuls test. $\mathrm{p}<0.05$ are considered to be statistically significant.

\section{Results}

CAPE concentration-dependently increased $\mathrm{H} 9 \mathrm{c} 2$ cell viability from $\mathrm{H}_{2} \mathrm{O}_{2}$ induced cell death

The effects of various $\mathrm{H}_{2} \mathrm{O}_{2}$ concentrations $(100-700 \mu \mathrm{M}, \mathrm{n}=8)$ on $\mathrm{H} 9 \mathrm{c} 2$ cell viability after incubation for 24 hours is illustrated in (Figure 1). $\mathrm{H} 9 \mathrm{c} 2$ cell viability increased slightly at $100 \mu \mathrm{M}$ and $200 \mu \mathrm{MH}_{2} \mathrm{O}_{2}$, but decreased in a concentration-dependent manner from $300 \mu \mathrm{M}$ to $700 \mu \mathrm{MH}_{2} \mathrm{O}_{2}$. The IC50 of $\mathrm{H}_{2} \mathrm{O}_{2}$ on $\mathrm{H} 9 \mathrm{c} 2$ cells cell viability was about $369 \mu \mathrm{M}$. At a concentration of $500 \mu \mathrm{M}, \mathrm{H}_{2} \mathrm{O}_{2}$ significantly decreased cell viability to $23 \pm 3 \%$ ( $\mathrm{p}<0.01 v s$ control). A $24 \mathrm{hr}$ treatment of $500 \mu \mathrm{MH}_{2} \mathrm{O}_{2}$ was used as an oxidative stress or to test if CAPE would mitigate oxidative stress.

We found that CAPE $(1-40 \mu \mathrm{M})$ alone was non-cytotoxic to H9c2 cells after incubation for $24 \mathrm{hr}$ (data not shown). Moreover, the solvent of CAPE DMSO $(<1 \%)$ did not show any cell death after administration for $24 \mathrm{hr}$ (data not shown). We further evaluated H9c2 cell viability after co-treatment of CAPE (1-40 $\mu \mathrm{M})$ and $500 \mu \mathrm{MH}_{2} \mathrm{O}_{2}$ for $24 \mathrm{hr}$. We found that CAPE $(1-40 \mu \mathrm{M})$ concentration-dependently increased cell viability when compared to $\mathrm{H}_{2} \mathrm{O}_{2}$ alone (Figure 2). The lower concentration CAPE $(1 \mu \mathrm{M})$ only slightly increased cell viability. By contrast, the intermediate concentration CAPE $(5 \mu \mathrm{M})$ began to show the significantly higher cell viability when compared to $\mathrm{H}_{2} \mathrm{O}_{2}$ alone $(\mathrm{p}<0.01)$. Moreover, the higher concentration CAPE (10$40 \mu \mathrm{M}$ ) completely reversed $\mathrm{H}_{2} \mathrm{O}_{2}$ caused cell damage and showed the similar cell viability as CAPE alone (all $\mathrm{p}<0.01$ vs $500 \mu \mathrm{M} \mathrm{H}_{2} \mathrm{O}_{2}$ ). The $\mathrm{EC}_{50}$ of CAPE on $\mathrm{H}_{2} \mathrm{O}_{2}$ induced cell damage is about $2 \mu \mathrm{M}$.

CAPE concentration-dependently reduced intracellular ROS in the presence of $\mathrm{H}_{2} \mathrm{O}_{2}$

$\mathrm{H}_{2} \mathrm{O}_{2} \quad(100-700 \mu M) \quad$ concentration-dependently increased intracellular ROS levels in $\mathrm{H} 9 \mathrm{c} 2$ cell when compared to the control baseline (Figure 3). In control cells, the ROS levels slightly increased by $0.06 \pm 0.04$ and $0.3 \pm 0.06$ fold at $1 \mathrm{hr}$. and $24 \mathrm{hr}$. when compared to the control baseline, respectively. The ROS levels showed a quick increase after $\mathrm{H}_{2} \mathrm{O}_{2}$ incubation within an hour. Thereafter, 100-300 $\mu \mathrm{MH}_{2} \mathrm{O}_{2}$ steadily increased ROS production over the $24 \mathrm{hrs}$, whereas 400-700 $\mathrm{MMH}_{2} \mathrm{O}_{2}$ showed a dramatic increase of ROS within $1 \mathrm{hr}$, then either plateaued or slightly reduced within $24 \mathrm{hr}$. From $1 \mathrm{hr}$ to $24 \mathrm{hr}, 500 \mathrm{MMH}_{2} \mathrm{O}_{2}$ maintained about a $2.95 \pm 0.6$ fold increases of intracellular ROS levels when compared to the control $(\mathrm{p}<0.05)$.

Intracellular ROS levels of H9c2 cells after co-treatment with CAPE $(1-40 \mu \mathrm{M})$ and $500 \mu \mathrm{MH}_{2} \mathrm{O}_{2}$ for $24 \mathrm{hr}$ is shown in (Figure 4). We found that CAPE concentration-dependently reduced intracellular ROS levels from $1 \mathrm{hr}$ throughout $24 \mathrm{hr}$. Lower concentration of CAPE 
$(1 \mu \mathrm{M})$ did not significantly reduced intracellular ROS levels when compared to that in $500 \mu \mathrm{MH}_{2} \mathrm{O}_{2}$. By contrast, higher concentrations of CAPE $(20 \mu \mathrm{M}$ and $40 \mu \mathrm{M})$ significantly reduced intracellular ROS to near basal levels $\left(\mathrm{p}<0.05 v s \mathrm{H}_{2} \mathrm{O}_{2} 500 \mu \mathrm{M}\right)$.

\section{CAPE reduced blood $\mathrm{H}_{2} \mathrm{O}_{2}$ levels in a hind limb I/R model}

We have demonstrated that oxidative stress could be induced by reperfusion for $45 \mathrm{~min}$ following prolonged ischemia (i.e., $30 \mathrm{~min}$ ) in rat hind limbs. We found that I/R limb had significantly higher blood $\mathrm{H}_{2} \mathrm{O}_{2}$ levels than blood $\mathrm{H}_{2} \mathrm{O}_{2}$ levels in non- $\mathrm{I} / \mathrm{R}$ limb [5,13]. In this study, we further confirmed that I $(30 \mathrm{~min}) / \mathrm{R}(60 \mathrm{~min})$ in hind limb significantly increased blood $\mathrm{H}_{2} \mathrm{O}_{2}$ levels to $2.1 \pm 0.8 \mu \mathrm{M}$ relative to the sham limb at 60 minutes' reperfusion in non-treated control rats $(\mathrm{n}=5)$. By contrast, CAPE $(0.95 \mathrm{mg} / \mathrm{Kg}$, equivalent to $40 \mu \mathrm{M}, \mathrm{n}=5)$ when given at reperfusion significantly reduced blood $\mathrm{H}_{2} \mathrm{O}_{2}$ levels from $35 \mathrm{~min}$ reperfusion and throughout the rest of experiment. The relative difference of blood $\mathrm{H}_{2} \mathrm{O}_{2}$ levels between $\mathrm{I} / \mathrm{R}$ limb and sham limb was $-0.4 \pm 0.3 \mu \mathrm{M}$ at 60 minutes' reperfusion (Figure 5).

\section{CAPE reduced myocardial infarction size and improved postreperfused cardiac function}

The cardiac functions among experimental groups are shown in (Figures 6-8). We found that untreated $\mathrm{I} / \mathrm{R}$ hearts $(\mathrm{n}=11)$ only recovered LVDP to $45 \pm 8 \%$, LVESP to $106 \pm 7 \%$, and $\mathrm{dP} / \mathrm{dtmax}$ to $33 \pm 5 \%$ of baseline values, respectively at the end of 60 minutes' reperfusion following 30 minutes ischemia. By contrast, CAPE (40 $\mu \mathrm{M}, \mathrm{n}=5$ ) when given at reperfusion for 5 minutes significantly restored LVDP to $75 \pm 15 \%$, LVESP to $133 \pm 13 \%$, and $\mathrm{dP} / \mathrm{dtmax}$ to $54 \pm 12 \%$ of baseline values, respectively (all $\mathrm{p}<0.05 v s$ control $\mathrm{I} / \mathrm{R}$ Figure 6-8). Moreover, CAPE also significantly reduced infarct size to $19 \pm 2 \%$ when compared to $30 \pm 6 \%$ in control I/R hearts ( $p<0.05$; Figure 9). There was no significant difference among heart rate and coronary flow among different groups.

We further evaluated if nitric oxide bioavailability or heme oxygenase- 1 are involved in CAPE's protective effects. We found that a non-selective NOS inhibitor, L-NAME $(50 \mu \mathrm{M}, \mathrm{n}=5)$, or a hemeoxygenase inhibitor, SnPPIX $(20 \mu \mathrm{M}, \mathrm{n}=5)$, significantly abolished all the cardioprotective effects of CAPE, respectively (all $\mathrm{p}<0.05$ vs CAPE treatment, Figures 6-9).

\section{Discussion}

This study showed that $\mathrm{H}_{2} \mathrm{O}_{2}(400-700 \mu \mathrm{M})$ significantly reduced $\mathrm{H} 9 \mathrm{c} 2$ cell viability in a concentration-dependent manner. The cell damage was possibly due to the significant increase of intracellular ROS levels. By contrast, co-treatment of CAPE $(5-40 \mu \mathrm{M})$ provided significant cyto-protection against an $\mathrm{H}_{2} \mathrm{O}_{2}$ insult, which may be contributed to the significant reduction of intracellular ROS. We also found that CAPE $(40 \mu \mathrm{M})$ when given at the beginning of reperfusion significantly decreased blood $\mathrm{H}_{2} \mathrm{O}_{2}$ levels during reperfusion when compared to the saline treatment. Moreover, CAPE $(40 \mu \mathrm{M})$ when given at the beginning of reperfusion significantly restored postreperfused cardiac function accompanied with reduction of infarct percentage. Inhibition of NOS or heme oxygenase-1 completely abolished CAPE's cardioprotective effects.

$\mathrm{H}_{2} \mathrm{O}_{2}$ is a widely used oxidant to simulate oxidative stress in vitro studies. We found that $\mathrm{H}_{2} \mathrm{O}_{2}$ exhibited opposite effects depending on its concentration. Lower concentrations (100-200 $\mu \mathrm{M})$ of $\mathrm{H}_{2} \mathrm{O}_{2}$ slightly increased cell viability, which may be related to redox signaling. By contrast, higher concentrations $(300-700 \mu \mathrm{M})$ of $\mathrm{H}_{2} \mathrm{O}_{2}$ concentration-dependently reduced cell viability. This is consistent with a previous $\mathrm{H}_{2} \mathrm{O}_{2}$-induced oxidative stress model in $\mathrm{H} 9 \mathrm{c} 2$ cells [15]. Sun. et al. found that $\mathrm{H}_{2} \mathrm{O}_{2}$ administration decreased cell viability in time-and concentration-dependent manners. More than $50 \%$ cell viability losses were seen after 6 hours incubation of 700 and $900 \mu \mathrm{M} \mathrm{H}_{2} \mathrm{O}_{2}$ [16]. Even in a transient exposure of 400 $\mathrm{MMH}_{2} \mathrm{O}_{2}$ to $\mathrm{H} 9 \mathrm{c} 2$ cells, it still can trigger time-dependent apoptosis [17]. The damaging effect of $\mathrm{H}_{2} \mathrm{O}_{2}$ may be related to the increase of intracellular ROS level. In this study, we showed that $\mathrm{H}_{2} \mathrm{O}_{2}$ quickly increased intracellular ROS levels within one hour and the increase lasted for 24 hours. Similarly, Kim et al showed intracellular ROS started to increase after only 5 minutes in $\mathrm{H} 9 \mathrm{c} 2$ cells treated with 500 $\mu \mathrm{M} \mathrm{H}_{2} \mathrm{O}_{2}$ [18]. Normally, intracellular $\mathrm{H}_{2} \mathrm{O}_{2}$ is degraded into $\mathrm{H}_{2} \mathrm{O}$ and oxygen by catalase or quenched by glutathione peroxidase. However, if $\mathrm{H}_{2} \mathrm{O}_{2}$ overwhelms cellular antioxidant capacity, the excessive $\mathrm{H}_{2} \mathrm{O}_{2}$ will propagate ROS formation through other mechanisms. One biological reaction critical in free radical generation is the Fenton reaction, where $\mathrm{H}_{2} \mathrm{O}_{2}$ decomposes by accepting an electron from a reduced metal ion (such as $\mathrm{Fe}^{2+}$ or $\mathrm{Cu}^{+}$) to form hydroxyl radicals. At high concentrations, superoxide and $\mathrm{H}_{2} \mathrm{O}_{2}$ can react with one another via Haber-Weiss reaction to produce a hydroxyl radical as well, further propagating ROS formation [2]. Higher level of $\mathrm{H}_{2} \mathrm{O}_{2}$ and the subsequent formation of potent hydroxyl radicals have been shown to contribute to pathologies such as inflammation, stroke, septic shock, and ischemia/reperfusion injury [1]. Additionally, it has been indicated that $\mathrm{H}_{2} \mathrm{O}_{2}$ transient exposure can trigger intracellular ROS production possibly from mitochondria [17]. On the other hand, studies have indicated that $\mathrm{H}_{2} \mathrm{O}_{2}$ can reduce intracellular antioxidant mechanisms, such as SOD activity or glutathione peroxidase [19], which may further exacerbate the oxidative stress induced by $\mathrm{H}_{2} \mathrm{O}_{2}$.

CAPE, a major component of honey bee hives, has been shown to have anti-oxidant effects against $\mathrm{H}_{2} \mathrm{O}_{2}$ caused cell damage [16]. In this study, we further confirm CAPE's cytoprotective effects when given as a co-treatment with $\mathrm{H}_{2} \mathrm{O}_{2}$. We also established a concentrationresponse relationship of CAPE and the $\mathrm{EC}_{50}$ of CAPE was $2 \mu \mathrm{M}$. Moreover, Wang et al showed CAPE pretreatment for 6 hours significantly protect HUVECs against menadione, another oxidative stress mimetic, induced cytotoxicity [20]. Another study showed that CAPE pretreatment for 5 hours provided beneficial effects on HUVECs against a transient insult of $2 \mathrm{mM} \mathrm{H}_{2} \mathrm{O}_{2}$. The $\mathrm{EC}_{50}$ of CAPE on HUVECs is about $8 \mu \mathrm{M}$ [21]. Meanwhile, the intracellular ROS levels were significantly reduced no matter if CAPE was given as co-treatment in this study or pretreatment in other studies [21]. Furthermore, the lipid peroxidation due to oxidative stress has been found to be reduced after CAPE administration [16]. The reduction of ROS levels can be contributed by direct quench effects of CAPE and/ or indirect mechanisms. It has been proposed that CAPE possesses chemical structure for free radical scavenging, such as hydroxyl group and/or catechol ring [22]. Additionally, it has been suggested that CAPE can upregulate intracellular anti-oxidant mechanisms, such as superoxide dismutase, glutathione peroxidase, and heme oxygenase-1 $[16,20]$.

Oxidative stress is a major contributor to I/R injury. Slezak, J et 
Citation: Castellano A, Lefkowitz D, Sandhu R, Kim A, Wieczorek P, et al. Caffeic Acid Phenethyl Ester Mitigates Oxidative Stress and Restores Vascular and Heart Function. J Cardiobiol. 2020;7(1): 7.

al. have shown that $\mathrm{I} / \mathrm{R}$ causes an increase of $\mathrm{H}_{2} \mathrm{O}_{2}$ in cardiac cells [4] Moreover, our lab also suggested that blood $\mathrm{H}_{2} \mathrm{O}_{2}$ levels are increased during reperfusion after a prolonged ischemia by inserting a $\mathrm{H}_{2} \mathrm{O}_{2}$ sensor into femoral veins to measure blood $\mathrm{H}_{2} \mathrm{O}_{2}$ levels in real-time in rats $[5,13,14]$. CAPE administration at the beginning of reperfusion showed significant reduction of blood $\mathrm{H}_{2} \mathrm{O}_{2}$ levels from 35 min to 60 min of reperfusion when compared to the saline control. The data further supports that CAPE exerts anti-oxidant effects in vivo. It has been reported that CAPE can be quickly hydrolyzed by esterase and exhibits a relatively short half-life in rat plasma [23]. However, CAPE is relatively stable in human plasma [24]. The major metabolite product of CAPE in plasma is caffeic acid, which is also an antioxidant [24]. CAPE and its metabolites may contribute to its antioxidant effects that lasted for an hour in this study.

We further found that CAPE given at the beginning of reperfusion could preserve postreperfused cardiac function and reduce infarct percentage. The cardioprotective effects of CAPE on $\mathrm{I} / \mathrm{R}$ injury have been indicated in regional ischemia/reperfusion and diabetic heart [25-27]. We found that the beneficial effects can be abolished by a NOS inhibitor or a heme oxygenase- 1 inhibitor. CAPE has been suggested to upregulate gene and protein expressions of heme oxygenase-1. CAPE can cause a near 20-fold increase in heme oxygenase-1 expression in HUVEC [20]. Scapagnini et al also showed that CAPE $(15-50 \mu \mathrm{M})$ upregulated heme oxygenase-1 expression in astrocytes after 6 or 24 hrs of treatment [28]. It has been discovered that the hydroxyl groups situated in the ortho position of the aromatic in CAPE are attributed to the induction of heme oxygenase-1 [29]. Furthermore, CAPE exerted its antioxidative effects through the Nrf2-mediated heme oxygenase-1 pathway and its anti-inflammatory effects through NF- $\kappa \mathrm{B}$ inhibition in murine macrophages and gingival fibroblasts [30]. Hemeoxygenase (HO) is the rate-limiting enzyme in the degradation of heme into free iron, carbon monoxide (CO) and biliverdin. heme oxygenase-1 is highly inducible by various stresses and may provide to play an important role in cellular protection against oxidative stress [31]. It has been indicated that biliverdin, bilirubin, and $\mathrm{CO}$ from heme oxygenase-1 related reaction have shown potent antioxidant, anti-inflammatory, or anti-apoptosis effects [20].

Additionally, endothelial-derived nitric oxide synthase (eNOS) may participate in CAPE's protective effects. Endothelial-derived NOS is an enzyme to produce nitric oxide normally in the presence of its substrate, L-arginine and essential co-factor, tetrahydrobiopterin. Endothelium-derived NO is a key regulator contributing to vascular homeostasis, such as facilitates blood flow, vasodilation, and antiinflammatory, and anti-coagulant [32]. However, it has been demonstrated that eNOS shifts its product from NO to SO under oxidative stress possibly due to oxidation of tetrahydrobiopterin to dihydrobiopterin [33]. We speculate that CAPE exerted direct/indirect anti-oxidant effect to reduce oxidative stress during reperfusion, which promoted normal activity of eNOS and subsequent normal vascular function. Better vasculature function would lead to better cardiac function and less cell damage. Therefore, blockade of eNOS activity by using non-selective NOS inhibitor would reduce CAPE's effects. Meanwhile, it has been shown that eNOS involves CAPE cardioprotective effects in a diabetic heart I/R model [27]. In another study, CAPE restores eNOS expression on vascular endothelium in high fructose corn syrup consumption rats [34].

In summary, this study provides new evidence of cytoprotective effects of CAPE against oxidative stress-induced cardiac cell and vascular/heart damage by its anti-oxidants properties and regulating hemeoxygenase-1 and nitric oxide synthase activity. It will be intriguing to further investigate if CAPE's protective effects and underlying mechanisms can be maintained after CAPE removal.

\section{References}

1. Cervantes Gracia K, Llanas-Cornejo D, Husi H (2017) CVD and Oxidative Stress. J Clin Med 6: 22.

2. Birben E, Sahiner UM, Sackesen C, Erzurum S, Kalayci O (2012) Oxidative stress and antioxidant defense. World Allergy Organ J 5: 9-19.

3. Higashi Y, Noma K, Yoshizumi M, Kihara Y (2009) Endothelial function and oxidative stress in cardiovascular diseases. Circ J 73: 411-418.

4. Slezak J, Tribulova N, Pristacova J, Uhrik B, Thomas T, et al. (1995) Hydrogen peroxide changes in ischemic and reperfused heart. Cytochemistry and biochemical and X-ray microanalysis. Am J Pathol 147: 772-781.

5. Teng JC, Kay H, Chen Q, Adams JS, Grilli C, et al. (2008) Mechanisms related to the cardioprotective effects of protein kinase $C$ epsilon (PKC epsilon) peptide activator or inhibitor in rat ischemia/reperfusion injury. Naunyn Schmiedebergs Arch Pharmacol 378: 1-15

6. Lee D, Bae S, Hong D, Lim H, Yoon JH, et al. (2013) $\mathrm{H}_{2} \mathrm{O}_{2}$-responsive molecularly engineered polymer nanoparticles as ischemia/reperfusiontargeted nanotherapeutic agents. Sci Rep 3: 2233.

7. Lee D, Park S, Bae S, Jeong D, Park M, et al. (2015) Hydrogen peroxideactivatable antioxidant prodrug as a targeted therapeutic agent for ischemiareperfusion injury. Sci Rep 5: 16592.

8. Bae S, Park M, Kang C, Dilmen S, Kang TH, et al. (2016) Hydrogen PeroxideResponsive Nanoparticle Reduces Myocardial Ischemia/Reperfusion Injury. J Am Heart Assoc 5: e003697.

9. Murtaza G, Karim S, Akram MR, Khan SA, Azhar S, et al. (2014) Caffeic acid phenethyl ester and therapeutic potentials. Biomed Res Int 2014: 145342.

10. Chen YJ, Shiao MS, Wang SY (2001) The antioxidant caffeic acid phenethy ester induces apoptosis associated with selective scavenging of hydrogen peroxide in human leukemic HL-60 cells. Anticancer Drugs 12: 143-149.

11. Dinc E, Ayaz L, Kurt AH (2017) Protective effect of combined caffeic acid phenethyl ester and bevacizumab against hydrogen peroxide-induced oxidative stress in human RPE cells. Curr Eye Res 42: 1659-1666.

12. Song JJ, Lim HW, Kim K, Kim KM, Cho S, et al. (2012) Effect of caffeic acid phenethyl ester (CAPE) on $\mathrm{H}_{2} \mathrm{O}_{2}$ induced oxidative and inflammatory responses in human middle ear epithelial cells. Int J Pediatr Otorhinolaryngol 76: $675-679$.

13. Perkins KA, Pershad S, Chen Q, McGraw S, Adams JS, et al. (2012) The effects of modulating eNOS activity and coupling in ischemia/reperfusion (I/R). Naunyn Schmiedebergs Arch Pharmacol 385: 27-38.

14. Chen Q, Parker CW, Devine I, Ondrasik R, Habtamu T, et al. (2016) Apocynin exerts dose-dependent cardioprotective effects by attenuating reactive oxygen species in ischemia/reperfusion. Cardiovas Pharm 5: 176-182.

15. Yang $X$, Jiang $H$, Shi $Y$ (2017) Upregulation of heme oxygenase-1 expression by curcumin conferring protection from hydrogen peroxide-induced apoptosis in $\mathrm{H} 9 \mathrm{c} 2$ cardiomyoblasts. Cell Biosci 7: 20.

16. Sun L, Wang K, Xu X, Ge M, Chen Y, et al. (2017) Potential Protective Effects of Bioactive Constituents from Chinese Propolis against Acute Oxidative Stress Induced by Hydrogen Peroxide in Cardiac H9c2 Cells. Evid Based Complement Alternat Med 2017: 7074147.

17. Han $\mathrm{H}$, Long $\mathrm{H}$, Wang $\mathrm{H}$, Wang J, Zhang $\mathrm{Y}$, et al. (2004) Progressive apoptotic cell death triggered by transient oxidative insult in $\mathrm{H} 9 \mathrm{c} 2$ rat ventricular cells: a novel pattern of apoptosis and the mechanisms. Am J Physiol Heart Circ 
Citation: Castellano A, Lefkowitz D, Sandhu R, Kim A, Wieczorek P, et al. Caffeic Acid Phenethyl Ester Mitigates Oxidative Stress and Restores Vascular and Heart Function. J Cardiobiol. 2020;7(1): 7.

Physiol 286: H2169-H2182.

18. Kim DS, Kim HR, Woo ER, Hong ST, Chae HJ, et al. (2005) Inhibitory effects of rosmarinic acid on adriamycin-induced apoptosis in H9c2 cardiac muscle cells by inhibiting reactive oxygen species and the activations of c-Jun N-terminal kinase and extracellular signal-regulated kinase. Biochem Pharmacol 70: 1066-1078.

19. Mao CY, Lu HB, Kong N, Li JY, Liu M, et al. (2014) Levocarnitine protects $\mathrm{H} 9 \mathrm{c} 2$ rat cardiomyocytes from $\mathrm{H}_{2} \mathrm{O}_{2}$-induced mitochondrial dysfunction and apoptosis. Int J Med Sci 11: 1107-1115.

20. Wang X, Stavchansky S, Kerwin SM, Bowman PD (2010) Structure-activity relationships in the cytoprotective effect of caffeic acid phenethyl ester (CAPE) and fluorinated derivatives: effects on heme oxygenase-1 induction and antioxidant activities. Eur J Pharmacol 635: 16-22.

21. Yang J, Marriner GA, Wang X, Bowman PD, Kerwin SM, et al. (2010) Synthesis of a series of caffeic acid phenethyl amide (CAPA) fluorinated derivatives: comparison of cytoprotective effects to caffeic acid phenethyl ester (CAPE). Bioorg Med Chem 18: 5032-5038.

22. Kiokias S, Proestos C, Oreopoulou V (2020) Phenolic Acids of Plant Origin-A Review on Their Antioxidant Activity In Vitro (O/W Emulsion Systems) Along with Their in Vivo Health Biochemical Properties. Foods 9: 534.

23. Yang J, Kerwin SM, Bowman PD, Stavchansky S (2012) Stability of caffeic acid phenethyl amide (CAPA) in rat plasma. Biomed Chromatogr 26: 594598.

24. Celli N, Dragani LK, Murzilli S, Pagliani T, Poggi A (2007) In vitro and in vivo stability of caffeic acid phenethyl ester, a bioactive compound of propolis. $J$ Agric Food Chem 55: 3398-3407.

25. Ince H, Kandemir E, Bagci C, Gulec M, Akyol O (2006) The effect of caffeic acid phenethyl ester on short-term acute myocardial ischemia. Med Sci Monit 12: BR187-BR193.
26. Cagli K, Bagci C, Gulec M, Cengiz B, Akyol O, et al. (2005) In vivo effects of caffeic acid phenethyl ester on myocardial ischemia-reperfusion injury and apoptotic changes in rats. Ann Clin Lab Sci 35: 440-448.

27. Ho YJ, Lee AS, Chen WP, Chang WL, Tsai YK, et al. (2014) Caffeic acid phenethyl amide ameliorates ischemia/reperfusion injury and cardiac dysfunction in streptozotocin-induced diabetic rats. Cardiovasc Diabetol 13: 98.

28. Scapagnini G, Foresti R, Calabrese V, Giuffrida Stella AM, Green CJ, et al. (2002) Caffeic acid phenethyl ester and curcumin: a novel class of heme oxygenase-1 inducers. Mol Pharmacol 61: 554-561.

29. Foresti R, Hoque M, Monti D, Green CJ, Motterlini R (2005) Differentia activation of heme oxygenase-1 by chalcones and rosolic acid in endothelial cells. J Pharmacol Exp Ther 312: 686-693.

30. Stahli A, Maheen CU, Strauss FJ, Eick S, Sculean A, et al. (2019) Caffeic acid phenethyl ester protects against oxidative stress and dampens inflammation via heme oxygenase 1. Int J Oral Sci 11: 6 .

31. Yachie A, Niida Y, Wada T, Igarashi N, Kaneda H, et al. (1999) Oxidative stress causes enhanced endothelial cell injury in human heme oxygenase-1 deficiency. J Clin Invest 103: 129-135.

32. Godo S, Shimokawa H (2017) Endothelial Functions. Arteriosclerosis, thrombosis, and vascular biology 37 : e108-e114.

33. Vasquez-Vivar J, Kalyanaraman B, Martasek P (2003) The role of tetrahydrobiopterin in superoxide generation from eNOS: enzymology and physiological implications. Free Radic Res 37: 121-127.

34. Gun A, Ozer MK, Bilgic S, Kocaman N, Ozan G (2016) Effect of caffeic acid phenethyl ester on vascular damage caused by consumption of high fructose corn syrup in rats. Oxid Med Cell Longev 2016: 3419479

\section{Acknowledgement}

The study was supported by Division of Research and Department of Bio-Medical Sciences at PCOM. 